EPiC Series in Engineering
Volume 3, 2018, Pages 394-398
HIC 2018. 13th International
Conference on Hydroinformatics

\title{
Flood control by water reservoir with account of runoff forecast.
}

\author{
Cavalli A.B. ${ }^{1}$, Ilinich V.V. ${ }^{1}$, Veliev I.G. ${ }^{1}$ \\ ${ }^{1}$ Russian state agrarian university - Moscow agricultural academy \\ abcavalli1993@gmail. com
}

\begin{abstract}
.
The research is aimed on development of providing additional information to the person making decisions regarding the flood control by water reservoir with help of both short term forecast of runoff together with stochastic forecast. The study proposes an approach to managing a complex reservoir that operates in rapidly developing summer floods, but at the same time during the year, but in different years there may be both floods and droughts, for which a large supply of water is needed reservoir.
\end{abstract}

\section{Introduction}

Every water reservoir must be ready to the control of catastrophic flood. The most dangerous situations can be on the catchments where torrential rains can have significant duration and intensity. Different situations can take place in same year intervals both water deficit and catastrophic flood. Traditionally, the regulation of the flow by water reservoirs in Russia is carried out using the dispatcher schedules that take into account the future uncertainty of the runoff to the reservoir, subject to planned water consumption of a normative probability of exceeding and real storage of water reservoir before concrete intra-annual time interval. Such graphs are not intended to promptly change the rules for regulating flow taking into account the runoff forecast. At present, it is possible to obtain a fairly accurate runoff forecast to the upcoming pentad (5 days) using different models of the "precipitationrunoff" type [1.2], since the time of the runoff concentration after the rain beginning is approximately 5 days, but a more prolonged forecast is desirable for more successful management of the reservoir 10 days. Such forecast we can't prolong on the base of models of the "precipitation-runoff" type. In this case, we propose a stochastic long term forecast of the runoff for one more pentad, which is based on the theory of a simple Markov chain. Accordingly, next problems were decided in the research: development of stochastic model of runoff to the water reservoir; estimation of errors in respect to the forecasted runoff at example of the observed catastrophic flood; testing of approach to flood control by water reservoir at the example of the observed catastrophic flood. 


\section{Methods and materials}

Krasnodar water reservoir was chosen by object of research, here rain floods have the fast process forming. The reservoir is located in the southern part of the Russia (North Caucuses) on the Kuban River. A significant part of the river basin is occupied by mountain territory and therefore a time of concentration of maximum water discharges is small. The river can have dangerous rain-ice floods during summer period. Inundations can occur during storm rains, the melting of glaciers did not influence significantly on increasing of the river runoff. The research used data observation, which were obtained during making of project according to scientific State Russian Contract \#9-/2- 2-2012 of Russian Hydrometeorological Center under management of director Vilfand R.M. Total data observation involved 33 years of daily water volumes of runoff to water reservoir.

. Usual water reservoir balance equation is base for all calculations in respect to every internal year interval $(t)$ which was taken 5 days in the research:

$$
V_{\text {end }}=V_{s t}+W-U-S
$$

where $V_{s t}$ and $V_{\text {end }}$ - water reservoir storage at the start and end of internal year interval accordingly; $W$ - river flow volume come in water reservoir; $U$ - water consumption volume including water losses from water reservoir; $S$ - water volume which outputs water reservoir without use for consumers. Precipitations, which fall down on the surface of water reservoir did not take in attention because there are not precipitations during dry period and value of that is small in comparatively to other compositions of water balance during flood period.

Preliminary for every intervals $t$ the statistical parameters of runoff $W$ (averages, variability and correlation coefficients between values of adjacent intervals) have been calculated by traditional method of moments. Coefficient of skewness was refined on the basis of a special approach with the help of non-standard characteristics [3,4] of the asymmetry, and a ratio (multiple of 0.5 ) between the coefficients of skewness and variation was established in the frame of special adapted gamma distribution of random values, which was used in the research.

The stochastic model is represented by the conditional functions of probability exceeding of pentad runoff according to theory of simple Markov chains. Such functions are determined on the base of the conditional statistical parameters for each pentad. Conditional statistical parameters (the average $W_{t, j}^{*}$ for the pentad and the coefficient of variation $C v_{t, j}^{*}$ ) were calculated by the following formulas:

$$
\begin{aligned}
& W_{t, j}^{*}=\hat{W}_{t}+R_{t / t-1} \times \delta_{t} / \delta_{t-1} \times\left(W_{t-1, j}^{*}-\hat{W}_{t-1}\right) \\
& C v_{t, j}^{*}=C v \times \hat{W}_{t} / W_{t, j}^{*} \times\left(1-R_{t / t-1}^{2}\right)^{0,5}
\end{aligned}
$$

where: $\hat{W}_{t}$ and $\hat{W}_{t-1}$ - averages of runoff volumes for intervals $t$ and $(t-1)$ accordingly; $\delta$ and $\delta-1$ - deviations of runoff volumes for intervals $t$ and $(t-1)$ accordingly; $R_{t / t-1}^{2}$ - correlative coefficient between runoff volumes of intervals $t$ and $(t-1)$ accordingly; $W_{t-1, j}^{*}$ - conditional average values of the runoff respecting of previous pentad $(t-1)$ which is taken from diapason $(j)$ of the runoff values; $C v_{t}$ - variation coefficient for the interval $t$.

Ratio of skewness coefficient to coefficient of variation was taken equal to determined before. 


\section{Result and discussion}

Complex of conditional probabilistic functions of runoff to the water reservoir for the June last pentad (26-30/06) is represented on Figure 1. According to Figure 1, for example: if runoff will be equal 1900 million $\mathrm{m}^{3}$ before the pentad (during previous internal year interval: $\mathrm{t}-1$ ), then the forecasted probabilistic function of runoff for next pentad $(\mathrm{t})$ will be represented by upper curve (1). If we will imagine that we are before pentad (t-1) than we can obtain a fairly accurate runoff forecast for the upcoming pentad (t-1) using models of the "precipitation-runoff" type [1,2], since the time of the runoff concentration after the rain beginning is approximately 5 days. However, a more prolonged forecast is desirable for more successful management of the reservoir - 10 days.

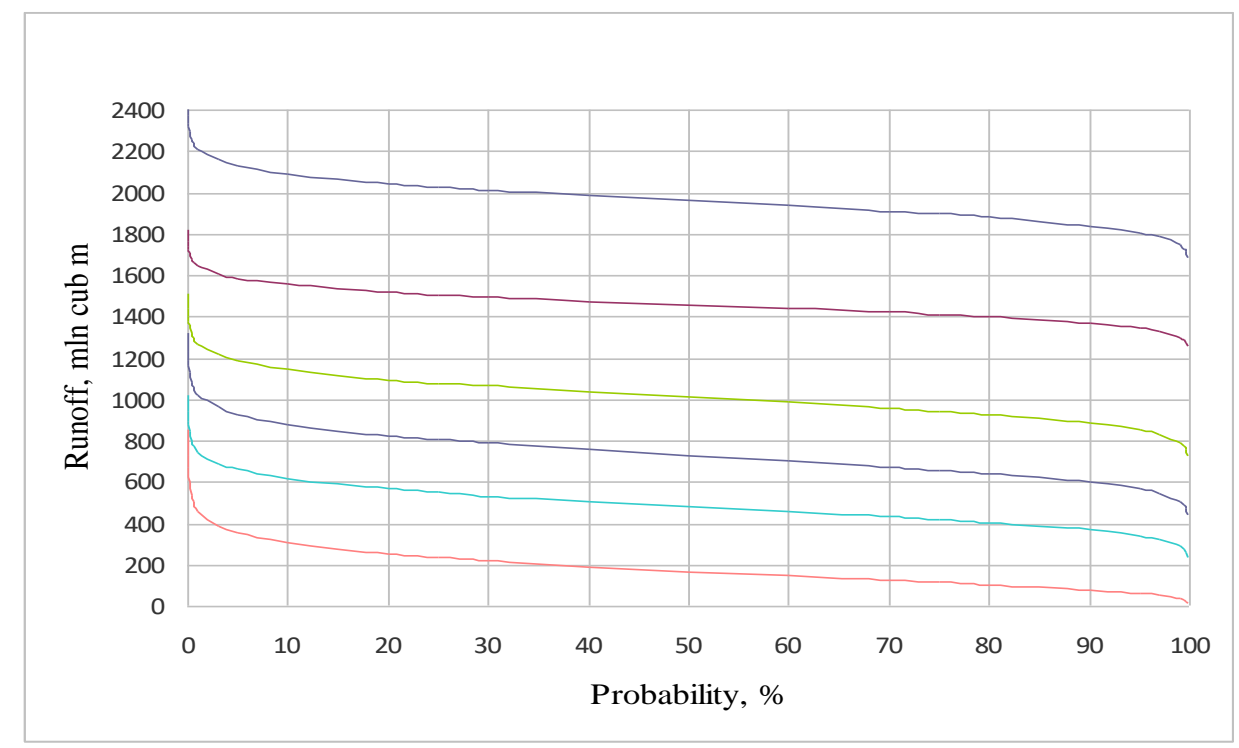

Figure 1: Conditional curves of probability exceeding of runoff for pentad period 26-30/06

Conditions of runoff during previous pentad $\mathrm{t}-1: 1$ ) $\mathrm{W}_{\mathrm{t}-1}=1900 \mathrm{mln} \mathrm{m}^{3}$ (upper curve); 2) $\left.\left.\left.\mathrm{W}_{\mathrm{t}-1}=1440 \mathrm{mln} \mathrm{m}^{3} ; 3\right) \mathrm{W}_{\mathrm{t}-1}=1100 \mathrm{mln} \mathrm{m}^{3} ; 4\right) \mathrm{W}_{\mathrm{t}-1}=777 \mathrm{mln} \mathrm{m}^{3} ; 5\right) \mathrm{W}_{\mathrm{t}-1}=550 \mathrm{mln} \mathrm{m}^{3}$;

6) $\mathrm{W}_{\mathrm{t}-1}=270 \mathrm{mln} \mathrm{m}^{3}$.

Thus the predicted runoff value for forthcoming pentad (t-1) is taken with help of short term forecasting. Practice has showed that their errors are not large and commensurate with the flow discharge measurements [1]. Then, according to the predicted value $\mathrm{W}_{\mathrm{t}-1}$, runoff of the next pentad $\left(\mathrm{W}_{\mathrm{t}}\right)$ can be determined with help of stochastic model of runoff to water reservoir. Forecast for 10 days is equal $\mathrm{W}_{\mathrm{t}-1}+\mathrm{W}_{\mathrm{t}}$. Runoff forecasts in comparison with real runoff are represented in Table 1

We can see that main share of errors do not exceed errors of runoff measurements (10-15\%), but there are exceptions for cases when future runoff values exceed value of previous pentad significantly. Such errors can be decreased by more accurate stochastic forecast due to increasing of amount of conditional curves. However, the obtained results give possibility to do water drafts from water reservoir before beginning of flood and to free part of useful storage, but then we have to know how much storage we need remain in water reservoir for consumption at the case of small runoff during 
Table 1: Comparison of runoff forecast with real runoff at example of flood during 2002

\begin{tabular}{ccccccc}
\hline Pentad & $\begin{array}{c}\text { Stochastic } \\
\text { forecast }\end{array}$ & $\begin{array}{c}\text { Real } \\
\text { runoff }\end{array}$ & $\begin{array}{c}\text { Error, } \\
\%\end{array}$ & $\begin{array}{c}\text { Forecast at } \\
10 \text { days }\end{array}$ & Real runoff & $\begin{array}{c}\text { Error, } \\
\%\end{array}$ \\
\hline $\begin{array}{c}\text { 1-5 June } \\
\text { 6-10 }\end{array}$ & 480 & 420 & 14,3 & 857 & 797 & 7,5 \\
$\begin{array}{c}\text { June } \\
11-15\end{array}$ & 425 & 377 & 12,7 & 845 & 797 & 6 \\
$\begin{array}{c}\text { June } \\
16-20\end{array}$ & 400 & 371 & 7,5 & 777 & 748 & 3,9 \\
June \\
$\begin{array}{c}21-25 \\
\text { June } \\
26-30\end{array}$ & 440 & 390 & 12,8 & 830 & 760 & 9,6 \\
June & 430 & 768 & 44 & 820 & 1158 & 29,2 \\
& 760 & 879 & 13,5 & 1518 & 1647 & 7,2
\end{tabular}

future pentad $(\mathrm{t})$. We need to add to the exact forecasted runoff $\mathrm{W}_{\mathrm{t}-1}$ practically guaranteed runoff value Wt. Such guaranteed runoff was taken equal to value of $95 \%$ probability. It was determined by the chosen conditional curve of probability. In our example, the accurate forecast of runoff $\left(\mathrm{W}_{\mathrm{t}-1)}\right.$ for pentad 21-25 June was equal $768 \mathrm{mln} \mathrm{m}^{3}$, accordingly conditional curve 4 was chosen on Figure $1\left(\mathrm{~W}_{\mathrm{t}-1}=777\right.$ $\mathrm{mln} \mathrm{m}^{3}$ ) and the forecast runoff $\left(\mathrm{W}_{\mathrm{t}}\right)$ of probability $95 \%$ was determined $560 \mathrm{mln} \mathrm{m}^{3}$. Summa of predicted values of runoff for two pentads consists $1237 \mathrm{mln} \mathrm{m}^{3}$, that is much more then plan consumption and more, then the permitted drafts. Therefore, during flood of 2002 there was necessary to do water drafts before. So we needed to do preliminary drafts were made during from 5 June until 15 June when runoff forecast for 10 days consisted $777 \mathrm{mln} \mathrm{m}^{3}$ and the plan consumption $573 \mathrm{mln} \mathrm{m}^{3}$, then the storage could be freed at $204 \mathrm{mln} \mathrm{m}^{3}$ before flood. Consequently, we can see on the Figure 2 graphs, which show less using of flood capacity for new approach to flood control, which takes into consideration runoff forecast.

Stochastic forecasts of runoff (on base o simple Markov chain) have limited accuracy, however they can help to the person making decisions regarding the flood control by water reservoir.

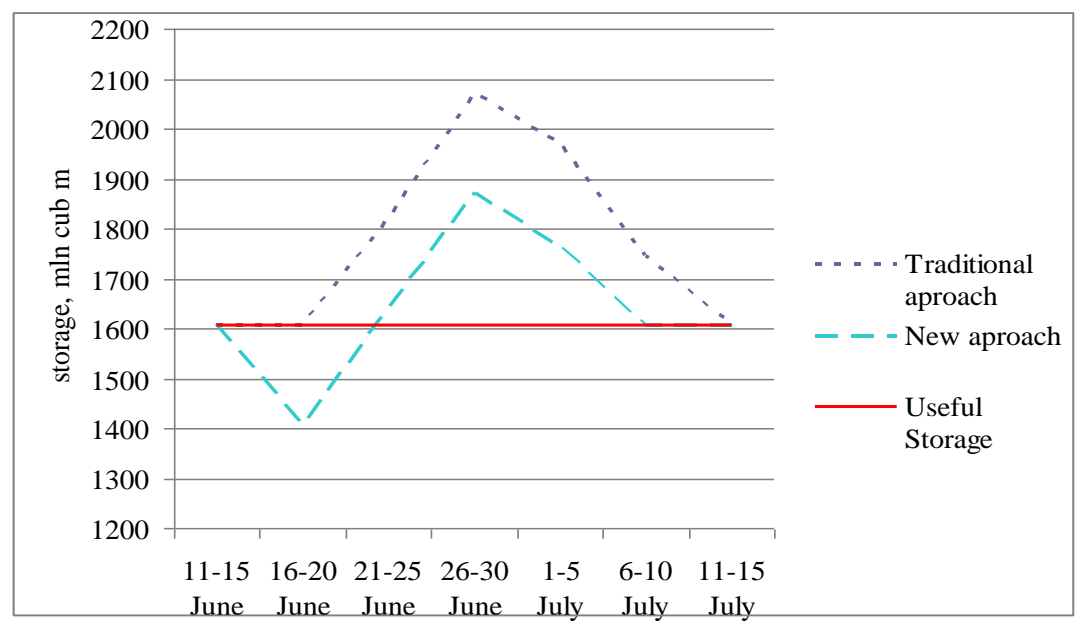

Figure 2: Graphs of use of flood capacity according to traditional and new approaches to flood control 


\section{Reference}

Borsch, S.V., Simonov Y.A. Operational system of short-term hydrological forecasts of water discharges for the Kuban basin rivers. Proceedings of the Russian Hydrometeorological Center Issue 349. - 2014. - pp. 63-87. (Rus).

Borsch, S.V., Simonov Y.A,. Khristoforov A.V. Flood forecasting and early warning system for rivers of the Black sea shore of Caucasian region and the Kuban river basin. Proceedings of the Russian Hydrometeorological Center. Issue 356 (Special). - 2014. - pp. 63-87. (Rus).

Ilinich V. V., Assessment of skew in the frames of three-parametric gamma distribution. Journal "Prirodoobustroystvo", -2010,-№5-pp.71-75, ISSN 1997-6011 (Rus).

Ilinich V. Evaluation of asymmetry for ranks of extreme hydrologic al values. Proceedings of Conference : "21 century: fundamental science and technology III", Vol. 3, North Charleston, SC, USA 29406, (2014) pp. 10-13.

Rules of use of water resources of the Krasnodar reservoir. Krasnodar - 2012.- P.193. (Rus). 